University of Nebraska - Lincoln

DigitalCommons@University of Nebraska - Lincoln

Agronomy \& Horticulture - Faculty Publications

Agronomy and Horticulture Department

2019

\title{
Relationships Between Wildfire Burn Severity, Cavity-Nesting Bird Assemblages, and Habitat in an Eastern Ponderosa Pine Forest
}

\author{
Emma C. Keele \\ University of Nebraska at Kearney, ekeele9@gmail.com \\ Victoria M. Donovan \\ University of Nebraska-Lincoln, vdonovan2@unl.edu \\ Caleb P. Roberts \\ University of Nebraska-Lincoln, caleb.powell.roberts@gmail.com \\ Sarah M. Nodskov \\ University of Nebraska-Lincoln \\ Carissa L. Wonkka \\ University of Nebraska-Lincoln, cwonkka2@unl.edu
}

See next page for additional authors

Follow this and additional works at: https://digitalcommons.unl.edu/agronomyfacpub

Part of the Agricultural Science Commons, Agriculture Commons, Agronomy and Crop Sciences Commons, Botany Commons, Horticulture Commons, Other Plant Sciences Commons, and the Plant Biology Commons

Keele, Emma C.; Donovan, Victoria M.; Roberts, Caleb P.; Nodskov, Sarah M.; Wonkka, Carissa L.; Allen, Craig R.; Powell, Larkin A.; Wedin, David A.; Angeler, David G.; and Twidwell, Dirac, "Relationships Between Wildfire Burn Severity, Cavity-Nesting Bird Assemblages, and Habitat in an Eastern Ponderosa Pine Forest" (2019). Agronomy \& Horticulture -- Faculty Publications. 1196.

https://digitalcommons.unl.edu/agronomyfacpub/1196

This Article is brought to you for free and open access by the Agronomy and Horticulture Department at DigitalCommons@University of Nebraska - Lincoln. It has been accepted for inclusion in Agronomy \& Horticulture -Faculty Publications by an authorized administrator of DigitalCommons@University of Nebraska - Lincoln. 


\section{Authors}

Emma C. Keele, Victoria M. Donovan, Caleb P. Roberts, Sarah M. Nodskov, Carissa L. Wonkka, Craig R. Allen, Larkin A. Powell, David A. Wedin, David G. Angeler, and Dirac Twidwell 


\title{
Relationships Between Wildfire Burn Severity, Cavity-Nesting Bird Assemblages, and Habitat in an Eastern Ponderosa Pine Forest
}

\author{
EMMA C. KEELE ${ }^{1}$ \\ Department of Biology, University of Nebraska at Kearney, Kearney 68849 \\ VICTORIA M. DONOVAN \\ Department of Agronomy $\mathcal{E}$ Horticulture, University of Nebraska-Lincoln, Lincoln 66583 \\ CALEB P. ROBERTS \\ Department of Agronomy $\mathcal{G}$ Horticulture, University of Nebraska-Lincoln, Lincoln 66583 \\ SARAH M. NODSKOV \\ School of Natural Resources, University of Nebraska-Lincoln, Lincoln 68583 \\ CARISSA L. WONKKA \\ Department of Agronomy E Horticulture, University of Nebraska-Lincoln, Lincoln 66583
}

CRAIG R. ALLEN

U.S. Geological Survey, Nebraska Cooperative Fish E Wildlife Research Unit, School of Natural Resources, University of Nebraska-Lincoln, Lincoln 66583

LARKIN A. POWELL

School of Natural Resources, University of Nebraska-Lincoln, Lincoln 68583

DAVID A. WEDIN

School of Natural Resources, University of Nebraska-Lincoln, Lincoln 68583

DAVID G. ANGELER

Department of Aquatic Sciences and Assessment, Swedish University of Agriculture Sciences, Uppsala, Sweden PO Box 7050

AND

DIRAC TWIDWELL

Department of Agronomy $\mathcal{E}^{2}$ Horticulture, University of Nebraska-Lincoln, Lincoln 66583

\begin{abstract}
Historically, eastern ponderosa pine (Pinus ponderosa) forests were described as sparse patches of old-growth trees maintained by frequent, low-severity fires; however, in recent decades, there have been a number of large mixed-severity wildfires throughout the range of these forests. Wildlife responses to severe fire disturbance in eastern ponderosa pine forests are not well understood. Our study investigates how cavity-nesting bird species in an eastern ponderosa pine forest are impacted by burn severity. The objectives of our study were to: (1) identify the community composition of cavity-nesting birds in a $27 \mathrm{y}$ old burn of mixed severity, (2) assess how habitat variables important to cavity-nesting birds differ in the mixedseverity fire, and (3) determine what habitat variables best predict bird occurrence $27 \mathrm{y}$ after mixed-severity fire. We surveyed 56 sites across four burn severity classes, ranging from
\end{abstract}

\footnotetext{
${ }^{1}$ Corresponding author present address: Department of Biology, University of Nebraska at Kearney, Kearney 68849; Telephone: (402) 469-1063; e-mail: ekeele9@gmail.com
} 
unburned to severely burned forest, in the Pine Ridge region of Nebraska. We measured multiple habitat characteristics (tree and snag diameter at breast height (DBH), coarse woody debris (CWD), tree and snag density, shrub height, and shrub cover) in May-August 2016 and conducted bird count surveys between 25 May and 8 June 2016. Cavity-nesting bird species' occurrence varied among the burn severity variables. Burn severity class (unburned, low severity, moderate severity, high severity) was a significant predictor of habitat characteristics for cavity-nesting birds, including tree density, snag density, mean snag DBH, variance in $\mathrm{DBH}$, and CWD, which also was the best indicator of cavity-nesting bird community composition. We report evidence that mixed-severity wildfires in eastern ponderosa pine forests create variation in habitat characteristics and cavity-nesting bird occurrence.

\section{INTRODUCTION}

Wildfire is a major ecological disturbance that can alter community composition and vegetation structure (Brown and Sieg, 1999; Hutto et al., 2016). Although ponderosa pine (Pinus ponderosa) forests are believed to have evolved under low to moderate severity wildfire regimes (Brown and Sieg, 1999), high severity fires have also recently been recognized as essential to historical fire regimes that maintain ecological diversity (Arno et al., 2000; Odion et al., 2014; Hutto et al., 2016). Multiple large, mixed-severity wildfires have occurred within eastern ponderosa pine forests in recent decades (MTBS, 2016; Donovan et al., 2017), leading to questions about how the ecological legacy of such disturbances will influence ecosystem structure. Variations in the timing, severity, and extent of wildfire can alter the ecological legacy left behind, such as remnant structures (coarse woody debris, snags) and species that shape ecosystem recovery (e.g., Schieck and Song, 2006; Johnstone et al., 2016). Therefore, the legacy of disturbance can alter the trajectory of ecosystem recovery or result in persistent alterations to ecosystem structure and function (Johnstone et al., 2016). Many studies have documented the response of western ponderosa pine forests following mixedseverity fire (e.g., Odion et al., 2014; Sherriff et al., 2014; Hutto et al., 2016), but little is known about the response of ponderosa pine on the eastern edge of its' range.

Eastern ponderosa pine forests can differ from western forests both geographically and ecologically. Eastern ponderosa pine distributions generally fall along a transition zone between ponderosa pine forests and grasslands (McPherson, 1997; Brown and Sieg, 1999), creating forest structure resembling savanna rather than western interior forests. Fires are often less frequent in interior forests compared to ponderosa pine savannas due to differences in fuel dynamics and topography (Brown and Sieg, 1999; Malamud et al., 2005). The grasslands that generally intersperse eastern ponderosa pine stands are more continuous and uniform in fine fuels, which can alter wildfire behavior (Brown and Sieg, 1999; Wienk et al., 2004). Moreover, eastern ponderosa pine forests generally occur along bluffs and hills, while greater topographic variation in western forests can create fuels that are more discontinuous (Dillon et al., 2011). Topography can also affect stand structure (Dillon et al., 2011; Kane et al., 2015) and species distributions by creating environmental gradients relating to factors like soil characteristics (Laughlin and Abella, 2007; Griffiths et al., 2009). The ecotonal nature of eastern ponderosa pine forests means their species compositions generally consist of both grassland and forest species (Johnsgard, 2001), creating communities that differ from those in interior western ponderosa pine forests. Therefore, inference regarding responses in eastern ponderosa pine forest to wildfires based on studies in western ponderosa pine forests may be limited. Because of differences in forest structure and fire dynamics, it remains unclear how the legacy effects of wildfire shape community structure and composition in eastern ponderosa pine forests. 
Many forest-dwelling species select for specific habitat characteristics created in mixedseverity wildfire, such as amphibians (France, 1997), bats (Weller and Zabel, 2001), mice (Gysel, 1961; Chambers, 2002), and birds (Lehmkuhl et al., 2003; Ganey and Vojta, 2004; Chambers and Mast, 2005). For cavity-nesting birds in particular, which have been shown to associate with the dead and fallen trees that can result from wildfire (e.g., Kotliar et al., 2002; Lohr et al., 2002; Martin et al., 2004), the forest structural characteristics created as a result of variation in burn severity are likely to play an essential role in shaping habitat. The response of cavity-nesting birds to the legacy effects of mixed-severity wildfires has been observed in many western ponderosa pine forested regions (e.g., Saab and Dudley, 1998; Kotliar et al., 2007; Dudley et al., 2012), but less is known on how cavity-nesting birds respond to the legacy of mixed-severity wildfires in eastern ponderosa pine forests. Many cavity-nesting bird species tend to respond positively in abundance and occupancy likelihood to burned areas due to increased snags for nesting substrate or foraging opportunities (Saab et al., 2005; Kalies et al., 2010; Latif et al., 2016), though cavity-nesting species' responses to wildfire can also range from neutral to negative based on severity, time since fire, and region (Saab and Powell, 2005; Smucker et al., 2005; Fontaine and Kennedy, 2012). Cavity-nesting species responses to wildfires can also vary in different regions based on the historical fire regime (Latif et al., 2016). Therefore, understanding the response of cavity-nesting birds to habitat created following mixed-severity wildfire across different regions of ponderosa pine is of high relevance to understanding the avian ecology of these systems.

Understanding how cavity-nesting birds respond to mixed-severity wildfire is vital information for the management of eastern ponderosa pine systems. In this study, we aim to understand what habitat characteristics influence cavity-nesting bird occurrence along a $27 \mathrm{y}$ old burn of mixed severity (ranging from unburned forests to high severity burned forest) in the Pine Ridge region of Nebraska. The Pine Ridge of northwestern Nebraska falls along the eastern border of the ponderosa pine range within the Great Plains (Raventon, 1994), and has experienced multiple mixed-severity wildfires in recent decades. The 1989 Fort Robinson wildfire is a mixed-severity wildfire that occurred within the Pine Ridge and has remained relatively unaltered by post-fire management, providing an example of longterm mixed-severity wildfire legacy effects in eastern ponderosa pine forests. Our objectives were to: (1) identify the community composition of cavity-nesting birds in a $27 \mathrm{y}$ old burn of mixed severity, (2) assess how habitat variables important to cavity-nesting birds differ in the mixed-severity fire, and (3) determine what habitat variables best predict bird occurrence 27 y after mixed-severity fire. To fulfill these objectives, we conducted bird surveys and vegetation sampling in unburned, low severity, moderate severity, and high severity burned patches of ponderosa pine forest within and surrounding the 1989 Fort Robinson mixedseverity wildfire perimeter.

\section{Methods \\ STUDY AREA}

Our study area was located within and surrounding the 1989 Fort Robinson wildfire which burned portions of both Fort Robinson State Park and Peterson Wildlife Management Area (WMA) in the Pine Ridge of northwestern Nebraska $\left(42^{\circ} 39^{\prime} 52^{\prime \prime} \mathrm{N}, 103^{\circ} 27^{\prime} 45^{\prime \prime} \mathrm{W}\right)$. Hereafter we refer to this study area as the Fort Robinson wildfire. Our study site was within the eastern edge of ponderosa pine distribution (Kartesz, 2015). The Pine Ridge is semi-arid (50.8 cm annual precipitation) and covers about $6993 \mathrm{~km}^{2}$ between the Great Plains and Rocky Mountain range (Tolstead, 1947; Kaul et al., 2011). The average elevation is approximately 


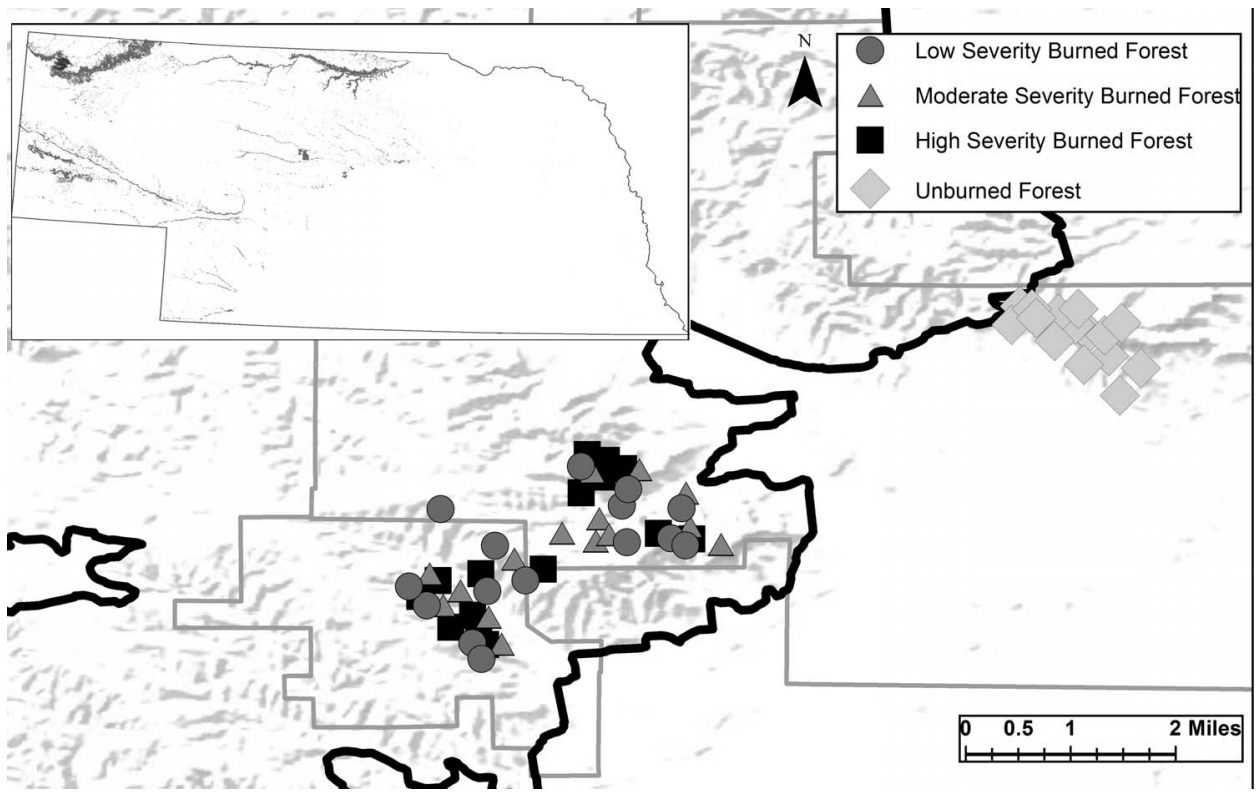

FIG. 1.-Our study area. The white box in the upper left corner shows Nebraska, where the dark green shaded areas in the northwestern corner shows the distribution of Ponderosa Pine (Pinus ponderosa) in the Pine Ridge region. The blackened area corresponds with the dark black outline of the larger map and indicates the perimeter of the 1989 Fort Robinson wildfire. Grey outlines indicate public land. The shapes indicate our sampling sites, where different shapes indicate different fire severities

1219 m (Johnsgard, 2001). The region consists of a mosaic of two unique ecosystems, eastern ponderosa pine forest interspersed with mixed grass prairie (Nixon, 1967), where fluctuations between each ecosystem are largely controlled by wildfire. Therefore, our study region hosts both forest and grassland breeding bird species (Johnsgard, 2001). Unlike many recent wildfires, very little post-fire management was conducted following the Fort Robinson wildfire. We excluded all areas that had subsequently burned following the Fort Robinson wildfire. As a result, we were able to measure a rare example of natural successional processes that occur following mixed-severity wildfire in an eastern ponderosa pine forest at our study sites.

\section{SURVEY SITE SELECTION}

We selected 56 survey sites within and surrounding the Fort Robinson wildfire. We distributed survey sites evenly in a stratified-random fashion over four burn severity classes in the ponderosa pine forest $(n=14)$ : unburned forest, low severity burn, moderate severity burn, and high severity burn (Fig. 1, ArcGIS 10.3). This sample size has been found to be adequate for delineating differences in bird community composition between habitat types (e.g., Petersen and Westmark, 2013; Schmidt et al., 2013). We obtained burn severity maps from Monitoring Trends in Burn Severity (MTBS) data for the Fort Robinson wildfire (MTBS, 2016). Burn perimeters and severities were designated by MTBS by analyzing the change in infrared reflectance values from satellite imagery using pre-fire and post-fire 
images. To determine survey site composition (forest or grassland) before the 1989 Fort Robinson wildfire, we used historic U.S. geological satellite imagery from Google Earth (Google Inc., 2009).

\section{HABITAT SAMPLING}

We conducted all habitat sampling during the summer of 2016 (May-August). To sample habitat characteristics, we created a single $30 \mathrm{~m}$ x $30 \mathrm{~m}$ quadrat at each study site $(\mathrm{n}=56)$, separated by a minimum of $100 \mathrm{~m}$. This quadrat size was chosen because it is the same size as the pixel resolution of the MTBS data, and therefore helped to ensure habitat characteristics we measured fell within the designated burn severity class. Tree density (Mills et al., 2000; Grundel and Pavlovic, 2007; Lesak et al., 2011), snag density (Kotliar et al., 2002; Martin et al., 2004), and snag diameter at breast height (DBH; Ganey and Vojta, 2004; Chambers and Mast, 2005) have been shown to be important variables in determining cavity-nesting bird occupancy. To characterize forest structure at each site, we recorded tree species, DBH, and status (either alive or dead) for every tree within the quadrat that was $\geq 2 \mathrm{~m}$ height and selfsupporting (Ganey, 1999). From these measurements we calculated mean stand density, mean stand $\mathrm{DBH}$, variation in stand $\mathrm{DBH}$, snag density, and mean snag DBH.

Fallen trees can provide important nesting habitat, predator cover, and insect food for cavity-nesting birds (Nally et al., 2000; Lohr et al., 2002). Therefore, we measured coarse woody debris (CWD) at each site by laying out a $30 \mathrm{~m}$ transect line within our $30 \mathrm{~m}$ by $30 \mathrm{~m}$ quadrat that intersected the midpoint of our plot at $15 \mathrm{~m}$. We randomized the transect line direction to run north-south or west-east at each individual site. To determine the percentage cover within our plots, we recorded the length of the transect line that was covered by CWD $\geq 10 \mathrm{~cm}$ diameter (Lohr et al., 2002).

Shrub structure (i.e., shrub height and shrub cover) can alter stand characteristics and provide foraging opportunities for cavity-nesting birds (Lesak et al., 2011; Kroll et al., 2014). It can also influence susceptibility to nest predation, where lower levels of shrub cover can allow better hunting visibility for birds of prey (Liebezeit and George, 2002; Kalies et al., 2010), while greater levels of cover can provide cover for small mammal nest predators (Liebezeit and George, 2002). We measured percentage of shrub cover and average shrub height at each site using five $5 \mathrm{~m}$ radius plots, arranged with one plot at the center of our 30 $\mathrm{m}$ by $30 \mathrm{~m}$ quadrat and four plots in the four cardinal directions, $15 \mathrm{~m}$ away from the center point (i.e., at the edges of our 30 by $30 \mathrm{~m}$ quadrat).

\section{BIRD COUNTS}

To measure cavity-nesting bird community composition, we conducted bird point count surveys during the breeding season, 25 May-8 June 2016, at all sites. In northwestern Nebraska, spring migration occurs from April to mid-May and the breeding season is midMay to June (Johnsgard, 2001). Although this time period overlaps with part of the migratory season, cavity-nesting species still reuse cavities during non-breeding season (Gentry and Vierling 2008). Survey points fell within the center of our $30 \mathrm{~m}$ by $30 \mathrm{~m}$ quadrats used to sample habitat characteristics. Surveys began $30 \mathrm{~min}$ before sunrise and ended $5 \mathrm{~h}$ after sunrise to coincide with peak hours of bird activity (Verner, 1988; Elliot and Johnson, 2017). We did not conduct surveys if wind speed exceeded $32 \mathrm{~km} / \mathrm{h}$ or if precipitation occurred (Grundel and Pavolvic, 2007). We recorded the presence-absence data for all species we detected by sight or sound during a $5 \mathrm{~min}$ period (e.g., Schmidt et al., 2013; Petersen and Westmark, 2013) within a $50 \mathrm{~m}$ radius from the sampling site (Petit et al., 
1995). Each site was surveyed twice within $5 \mathrm{~d}$ to increase representation of the cavity-nesting bird community (Sliwinski et al., 2015).

\section{STATISTICAL ANALYSES}

First, we wanted to identify patterns in cavity-nesting bird community composition among the four burn severity classes. To do this, we calculated the total number of sites cavitynesting species were recorded at in each burn severity class to determine differences in cavity-nesting bird species richness. We also recorded the number of sites that each cavitynesting bird species was recorded at within each burn severity category.

Secondly, we wanted to determine if habitat variables selected for by cavity-nesting birds differ between burn severities $27 \mathrm{y}$ after fire. We determined if burn severity was a significant predictor of each habitat characteristic with linear regressions, setting burn severity as the independent (or predictor variable) and each habitat characteristic as the dependent variable within separate models. Habitat characteristics used as dependent variables included: mean stand density, mean stand $\mathrm{DBH}$, variation in stand $\mathrm{DBH}$, snag density, mean snag DBH, shrub height, shrub cover, and CWD, resulting in a total of eight linear models. We used diagnostic plots to confirm that model assumptions were met. We applied square root transformations where necessary to improve normality and reduce heteroscedasticity of residuals. We then used multiple comparisons of slopes for each linear regression to compare amongst burn severities (Hothorn et al., 2008).

Third, we wanted to determine what habitat features that varied among burn severity classes influenced cavity-nesting bird occurrence. To identify the relationship between cavitynesting bird occurrence and habitat variables, we conducted a Redundancy Analysis (RDA). RDA is a form of constrained ordination that examines how much the amount of variation in one set of variables can explain the amount of variation in another set of variables. In our analysis, habitat variables that were found to significantly differ between burn severities in our linear regression analysis were used to explain variation in bird species presence-absence at each site. Because our data contained rare species, we applied a Hellinger Transformation to our bird species data before inputting our data into RDA (Legendre and Gallagher, 2001). To determine which habitat variables were best at describing bird presence-absence within a site, we used stepwise model selection for constrained ordination (Oksanen et al., 2016). We first tested for multi-collinearity among all habitat variables that varied significantly among burn severities using variance inflation factors (VIF). VIF values did not suggest high levels of multi-collinearity (VIF values ranging from 1.15 to 3.05), therefore all habitat variables that were found to significantly differ between burn severities were included within our stepwise modelling selection procedure. We then used stepwise model selection that used permutation tests to sequentially select between different combinations of habitat variables by adding and removing different variables from the intercept and global models following the steps outlined by Oksanen (2012). This resulted in a single best model that could be used to describe bird presence-absence at different sites.

\section{RESULTS}

\section{CAVITY-NESTING BIRDS}

We observed 10 species of cavity-nesting birds and recorded cavity-nesting bird presence at 35 of the 56 sites sampled. The highest cavity-nesting species richness was at unburned sites $(\mathrm{n}=8)$, and the lowest was at moderately burned sites $(\mathrm{n}=4)$. We observed five and six species in high and low burned sites respectively. The number of sites cavity-nesting birds 
were recorded at varied greatly among the burn severity classes (Fig. 2). Northern flicker (Colaptes auratus) and red-headed woodpecker (Melanerpes erythrocephalus) were the only two species not observed in unburned forest; both species were predominantly found at low severity and high severity burned sites. Conversely, the house wren (Troglodytes aedon) and black-capped chickadee (Poecile atricapillus) occurred mostly in unburned forest and occurred less frequently at sites that had burned at increasing fire severity. Both the pygmy nuthatch (Sitta pygmaea) and red-breasted nuthatch (Sitta canadensis) were the rarest species recorded during our surveys and were only found in the unburned forest (Fig. 2).

\section{HABITAT CHARACTERISTICS}

Multiple different habitat characteristics important to cavity-nesting birds varied among the burn severity classes. Burn severity class (ranging from unburned forest to forest that burned at high severity) was a significant predictor of tree density $\left(F_{3,56}=35.34, R^{2}=0.81, \mathrm{P}\right.$ $<0.01)$, snag density $\left(F_{3,56}=17.21, R^{2}=0.54, \mathrm{P}<0.01\right)$, mean snag DBH $\left(F_{3,27}=3.17, R^{2}=\right.$ $0.14, \mathrm{P}=0.04)$, variance in DBH $\left(F_{3,42}=5.71, R^{2}=0.34, \mathrm{P}<0.01\right)$, and CWD $\left(F_{3,56}=16.74\right.$, $\left.R^{2}=0.47, \mathrm{P}<0.01\right)$. Burn severity class was not a significant predictor of mean tree DBH $\left(F_{3,42}=0.91, R^{2}=0.09, \mathrm{P}=0.44\right)$, shrub height $\left(F_{3,39}=1.15, R^{2}=0.02, \mathrm{P}<0.34\right)$ or shrub cover $\left(F_{3,56}=1.20, R^{2}=0.06, \mathrm{P}=0.32\right)$.

Tree density was highest in unburned sites and lowest in sites that burned at high severity (Fig. 3A). Tree density differed between high vs. low, unburned vs. high, unburned vs. low, and unburned vs. moderate burned sites (Table 1; Fig. 3A). Snag density was also highest at unburned sites (Fig. 3B). Snag density differed between unburned vs. high, unburned vs. low, and unburned vs. moderate (Table 1; Fig. 3B), however did not differ among low, moderate or high burn severities. Mean snag DBH was largely similar between burn severities (Fig. 3D), only significantly differing between unburned vs. moderate burned sites (Table 1; Fig. 3D). There was no significant difference in CWD cover between high vs. moderate sites or between low vs. unburned sites (Table 1; Fig. 3F). CWD cover was significantly greater at high and moderate sites compared to low and unburned sites (Table 1; Fig. 3F). Variance in DBH was lowest in unburned and moderate burned sites and highest in low and high severity burned sites (Fig. 3E). Variance in DBH differed most between unburned vs. high and unburned vs. low severity burned sites (Table 1; Fig. 3E). Mean DBH, shrub cover, and mean shrub height did not differ across burn severities (Table 1; Figs. 3C, G,H).

\section{HABITAT VARIABLES THAT DESCRIBE BIRD DISTRIBUTION}

Stepwise model selection indicated that CWD was the best indicator of cavity-nesting bird community composition $\left[F_{1}=3.54, \mathrm{P}=0.01\right]$ relative to all combinations of measured variables. In our ordination, $9 \%$ of the variance was explained by the constrained axis (Table 2; Table 3). Ordination revealed that sites with more CWD tended to have more northern flicker and red-headed woodpeckers in them (Fig. 4).

\section{DiscusSION}

Both cavity-nesting birds and habitat characteristics varied across our four burn severity classes in an eastern ponderosa pine forest. Although multiple habitat characteristics previously identified as deterministic of cavity-nesting bird communities (e.g., snag density, tree density, mean snag $\mathrm{DBH}$, and variance in $\mathrm{DBH}$ ) varied among burn severity classes, CWD best explained the variation in cavity-nesting bird distributions seen in our study. Our 


\section{HAWO}

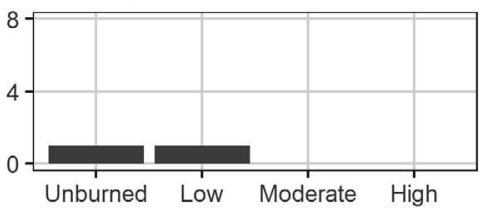

NOFL

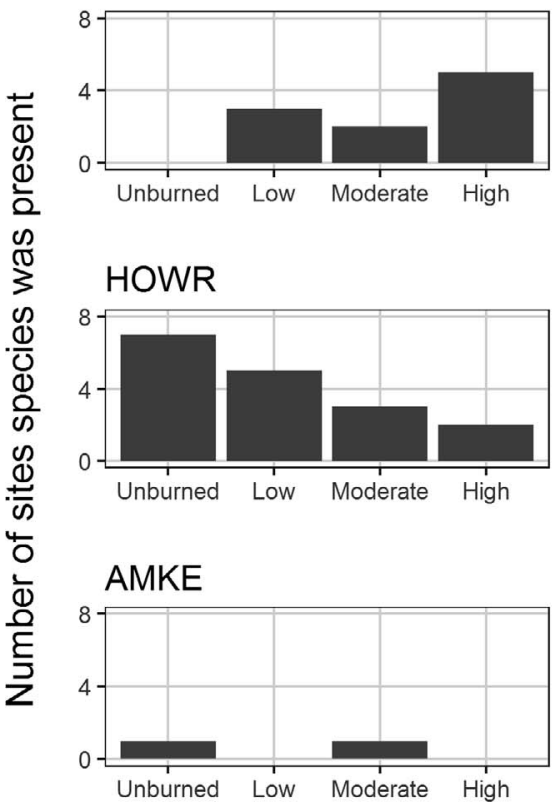

PYNU

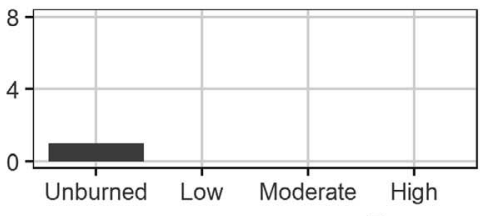

RHWO

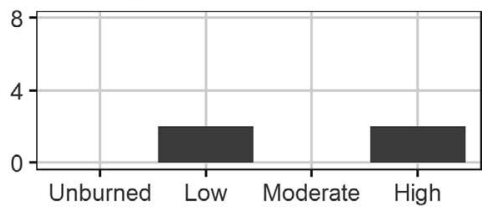

EABL

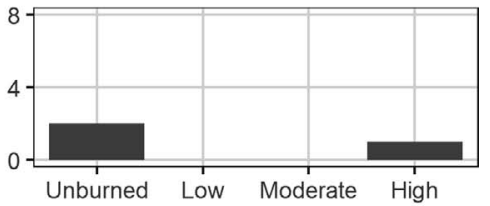

MOBL

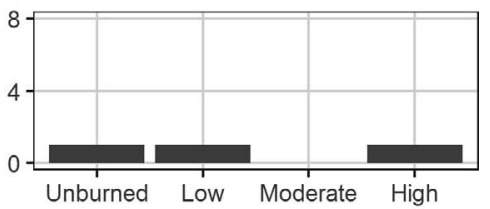

$\mathrm{BCCH}$

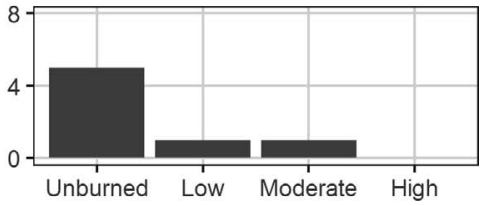

RBNU

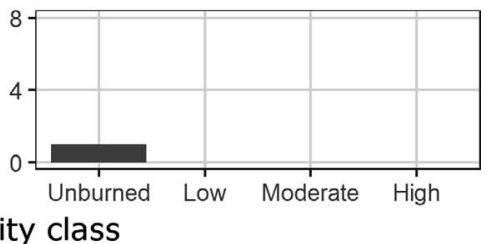

Fig. 2.-The number of sites cavity-nesting bird species were recorded at for each burn severity class from the 1989 Fort Robinson wildfire in Nebraska during May and June 2016. Lettering represents the American Ornithological Union (AOU) alpha codes for each bird species: hairy woodpecker (HAWO), red-headed woodpecker (RHWO), northern flicker (NOFL), eastern bluebird (EABL), house wren (HOWR), mountain bluebird (MOBL), American kestrel (AWKE), black-capped chickadee (BCCH), pygmy nuthatch (PYNU), red-breasted nuthatch (RBNU) 

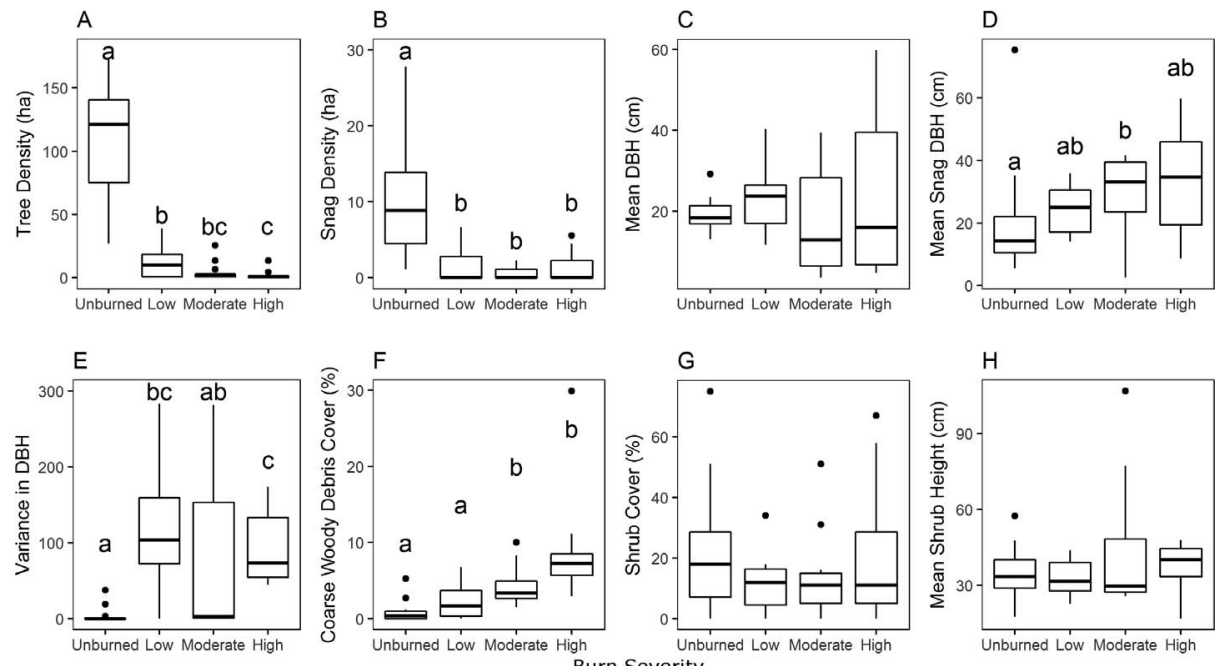

FIG. 3.-Habitat characteristics among four burn severity classes sampled after the 1989 Fort Robinson wildfire in the Pine Ridge region of Nebraska during May-August 2016. Box plots shows the mean of (A) tree density, (B) snag density, (C) mean DBH, (D) mean snag DBH, (E) variance DBH, (F) CWD, (G) shrub cover, and $(\mathrm{H})$ mean shrub height. Burn severities with different letters indicate a high probability that differences observed between burn severity classes were not due to random chance

results suggest that mixed-severity burns and the structural legacies that persist for decades post-fire are important factors influencing cavity-nesting bird distributions in eastern ponderosa pine forests.

Variation in cavity-nesting bird community composition was best explained by CWD. Lohr et al., (2002) similarly observed that CWD strongly influenced breeding bird abundance and diversity in a loblolly pine (Pinus taeda) forest, where the removal of CWD and snags reduced breeding bird abundance by $50 \%$ and richness by $45 \%$. CWD is important to cavity-nesting birds because it provides structures for perching, foraging, communicating, and nesting (Lohr et al., 2002; Hutto and Gallo, 2006). In our study site, CWD generally increased with increasing fire severity, where sites that had burned at high severity had the greatest CWD cover. Similarly, we found that certain species (primarily northern flickers and red-headed woodpeckers) were strongly associated with sites with high levels CWD. CWD has been associated with providing breeding habitat, foraging options, and nesting opportunities (Lohr et al., 2002), which could suggest the potential benefits of high severity fire to certain cavity-nesting birds. In a study in western ponderosa pine forest, Saab and Dudley (1998) observed that northern flickers and hairy woodpeckers (Leuconotopicus villosus) occurred most in areas with high numbers of snags and CWD. In our study, both the northern flicker and red-headed woodpecker were solely observed in burned areas where there were higher levels of CWD, while hairy woodpeckers were more associated with unburned sites or sites that burned at low severity. This suggests that cavity-nesting species may respond differently to habitat characteristics created by varying burn severities among regions. Other studies have also found "mixed" responses of bird species to fire severity or variation in time since fire (Kotliar et al., 2002; Smucker et al., 2005). The greatest diversity of cavity-nesting bird species was found in unburned forest which had the lowest CWD ground cover, suggesting 
TABle 1.-Estimates $(\beta)$ and P-values (P) for multiple comparisons of burn severity class for habitat characteristics in the 1989 Fort Robinson wildfire. Boldface values indicate statistically significant $(\mathrm{P} \leq$ 0.05 ) differences between pairs. Because our sample size among groups was equal, standard error values represent the standard error of the model

\begin{tabular}{|c|c|c|c|c|c|c|c|c|c|}
\hline & \multicolumn{3}{|c|}{ High vs. low } & \multicolumn{3}{|c|}{ High vs. moderate } & \multicolumn{3}{|c|}{ High vs. unburned } \\
\hline & $\beta$ & $\mathrm{SE}$ & $\mathrm{P}$ & $\beta$ & $\mathrm{SE}$ & $\mathrm{P}$ & $\beta$ & $\mathrm{SE}$ & $\mathrm{P}$ \\
\hline CWD & 0.26 & $7.56 \times 10^{-4}$ & $<\mathbf{0 . 0 1}$ & $3.98 \times 10^{-3}$ & $7.56 \times 10^{-4}$ & 0.44 & 1.34 & $7.56 \times 10^{-4}$ & $<0.01$ \\
\hline Tree Density & -3.06 & 0.45 & 0.05 & -0.26 & 0.45 & 0.87 & -82.47 & 0.45 & $<\mathbf{0 . 0 1}$ \\
\hline Snag Density & $7.84 \times 10^{-4}$ & 0.13 & 1 & 0.09 & 0.13 & 0.83 & -5.15 & 0.13 & $<\mathbf{0 . 0 1}$ \\
\hline Mean Snag DBH & 0.08 & 0.84 & 0.99 & 0.31 & 0.84 & 0.93 & -3.76 & 0.84 & 0.16 \\
\hline Mean DBH & -0.51 & 0.61 & 0.79 & $-5.82 \times 10^{-3}$ & 0.61 & 1.0 & -2.56 & 0.61 & 0.19 \\
\hline Shrub Height & 3.38 & 6.03 & 0.94 & -3.49 & 6.03 & 0.94 & 1.30 & 6.03 & 1 \\
\hline Shrub Cover & 0.68 & 0.54 & 0.68 & 0.58 & 0.54 & 0.73 & -0.11 & 0.54 & 0.97 \\
\hline Variance DBH & 9.92 & 3.47 & 0.33 & 36.30 & 3.47 & 0.01 & 90.94 & 3.47 & $<0.01$ \\
\hline
\end{tabular}

that there are likely multiple other factors that interact to drive cavity-nesting bird occupancy patterns.

Variation in bird species distribution could be the result of niche partitioning driven by the competitive interactions that exist in biological communities (Bregman et al., 2015). The ten species we observed can be categorized into the following three excavator groups according to Martin et al., (2004): primary excavators (actively excavate cavities; red-headed woodpecker, northern flicker, and hairy woodpecker), weak excavators (expand on previously excavated cavities or infrequently excavate on their own; black-capped chickadee, pygmy nuthatch, and red-breasted nuthatch), and secondary nesters (rely on previously excavated cavities; eastern bluebird (Sialia sialis), house wren, mountain bluebird (Sialia currucoides), and American kestrel (Falco sparverius)). When we divide our data in this fashion, we observe that species within the same excavator group did not always occupy the same burn severity. For example, northern flickers and red-headed woodpeckers were only found in burned forests, while hairy woodpeckers were found in both unburned and burned forests. Differences in the distribution of primary excavators could be the result of niche partitioning related to limits in foraging (Hutto, 1995) and nesting opportunities (Saab and Dudley, 1998; Chambers and Mast, 2005). Similarly, there was a high level of variation in secondary nester occupancy of burn severities. All of the secondary nesters (eastern bluebird, mountain bluebird, and American kestrel) were equally observed in burned and unburned sites, except for the house wren that was predominantly observed in unburned sites. This may be because weak excavators and secondary nesters are less competitive compared to primary excavators, so they are able to occupy a wider breadth of niches

TABLE 2.-The partitioning of variance resulting from redundancy analysis (RDA) of cavity-nesting bird species abundance across sites, with coarse woody debris as the constraining variable. Inertia represents the variance in the transformed species abundance

\begin{tabular}{lcc}
\hline \hline & Inertia & Proportion \\
\hline Total & 1.07 & 1.00 \\
Constrained & 0.10 & 0.09 \\
Unconstrained & 0.96 & 0.91 \\
\hline
\end{tabular}


TABLE 1.-Extended

\begin{tabular}{|c|c|c|c|c|c|c|c|c|}
\hline \multicolumn{3}{|c|}{ Moderate vs. low } & \multicolumn{3}{|c|}{ Low vs. unburned } & \multicolumn{3}{|c|}{ Moderate vs. unburned } \\
\hline B & $\mathrm{SE}$ & $P$ & $\beta$ & $\mathrm{SE}$ & $P$ & $\beta$ & $\mathrm{SE}$ & $\mathrm{P}$ \\
\hline 0.05 & $7.56 \times 10^{-4}$ & 0.03 & 0.02 & $7.56 \times 10^{-4}$ & 0.14 & 0.46 & $7.56 \times 10^{-4}$ & $<0.01$ \\
\hline-1.54 & 0.45 & 0.25 & -53.75 & 0.45 & $<\mathbf{0 . 0 1}$ & -73.51 & 0.45 & $<0.01$ \\
\hline-0.11 & 0.13 & 0.79 & -5.07 & 0.13 & $<0.01$ & -6.69 & 0.13 & $<\mathbf{0 . 0 1}$ \\
\hline-0.08 & 0.84 & 0.98 & -4.90 & 0.84 & 0.08 & -6.25 & 0.84 & 0.04 \\
\hline-0.41 & 0.61 & 0.85 & -0.78 & 0.61 & 0.67 & -2.32 & 0.61 & 0.22 \\
\hline 6.88 & 0.63 & 0.67 & -2.09 & 0.63 & 0.99 & 4.79 & 0.63 & 0.86 \\
\hline $3.85 \times 10^{-3}$ & 0.54 & 1 & -1.33 & 0.54 & 0.41 & -1.19 & 0.54 & 0.45 \\
\hline-8.27 & 3.47 & 0.42 & 40.70 & 3.47 & $<0.01$ & 12.32 & 3.47 & 0.25 \\
\hline
\end{tabular}

(Martin et al., 2004). Kotliar et al., (2002) similarly found that some species did not have a clear trend associated with burn severity class. Specifically, they recorded 18 cavity-nesting birds in western Montana as having "mixed" responses.

The black-capped chickadee and house wren are weak and secondary excavators respectively; we found that that these two species predominantly occurred in unburned forests. In a study conducted in western ponderosa pine forests, Kotliar et al., (2007) alternatively reported that house wrens had highest densities in high-severity burned areas, as they are generally associated with snags. Our findings report that snag density was highest in unburned forests, rather than burned forests. This suggests that our results are consistent with Kotliar et al., (2007) in that we found that house wrens favored areas with the highest snag density, however our sites differed in stand structures. Whether differences in snag density are related to differences between eastern and western ponderosa pine stand structure and ecology or differences in time since fire is unclear. Time since fire is an important component contributing to the retention rate of snags. Over time, snags fall and decompose, and some insects only occur in dead logs for a short duration immediately following a wildfire (McHugh et al., 2003). Chambers and Mast (2005) observed that $7 \mathrm{y}$ after a fire in northern Arizona, $41 \%$ of the snags had fallen. We sampled the Fort Robinson wildfire $27 \mathrm{y}$ after it occurred, and, though we observed the highest rates of snags in unburned forest, we still observed large snags standing in burned areas. Lack of sequential measures after wildfire make it difficult to determine the impacts of time since fire on our study site. Past studies in central New Mexico and western Montana have also found that eastern bluebird and mountain bluebirds occur at the highest densities in high severity

TABLE 3.-Eigen values for the first two axes, RDA1 (constrained variability, coarse woody debris) and PC1 (unconstrained variability), from redundancy analysis (RDA) of cavity-nesting bird abundance across sites, with coarse woody debris as the constraining variable

\begin{tabular}{lcc}
\hline \hline & RDA1 & PC1 \\
\hline Eigenvalue & 0.10 & 0.28 \\
Proportion Explained & 0.09 & 0.26 \\
Cumulative proportion & 0.09 & 0.36 \\
\hline
\end{tabular}




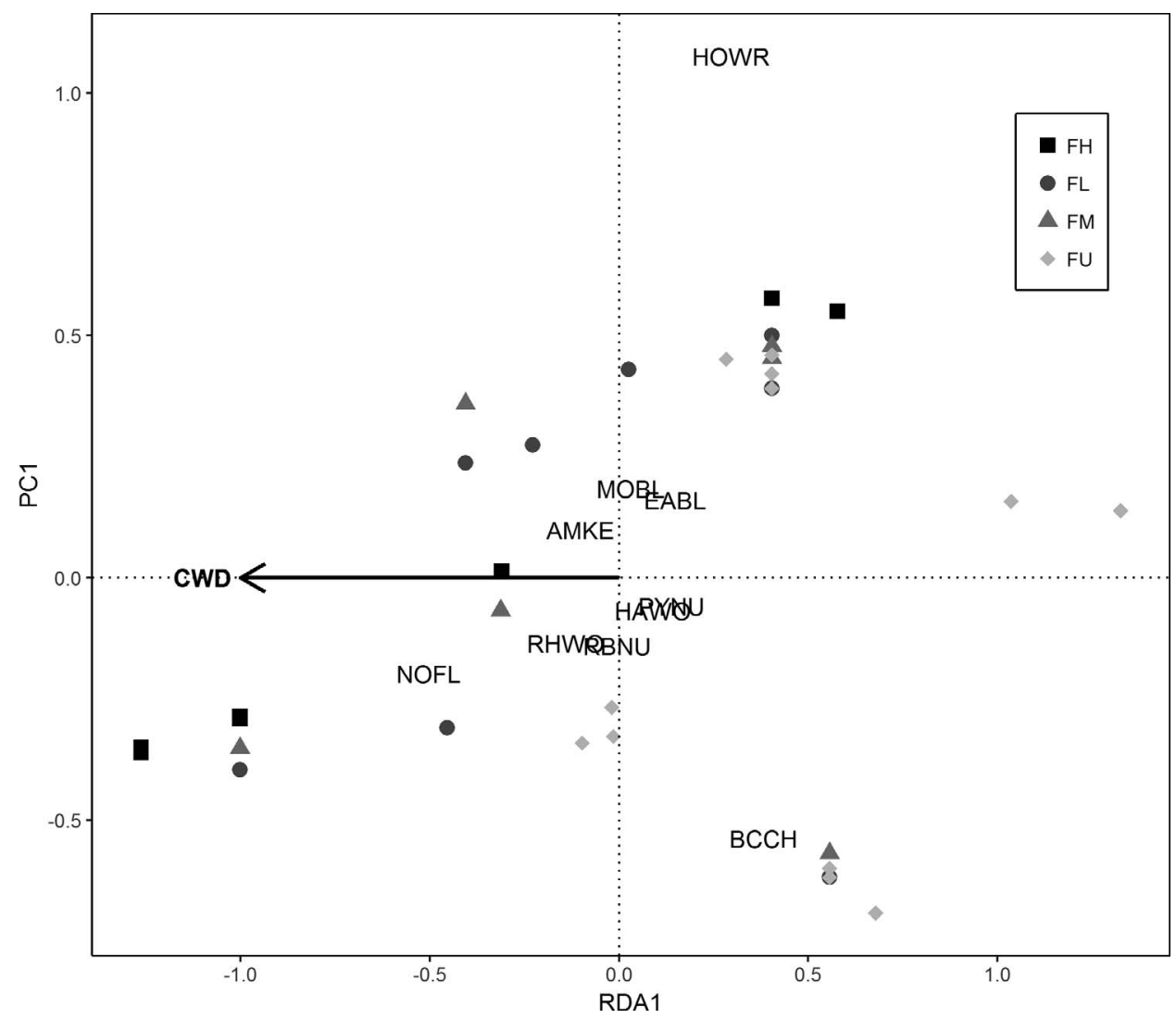

FIG. 4.-Ordination of the cavity-nesting bird community, illustrating relationships with coarse woody debris (CWD). RDA1 represents the constrained axis (CWD) and PC1 represents the unconstrained (residual) variability. Each shaped point represents a site and its burn severity type ( $\mathrm{FH}=$ high severity, $\mathrm{FL}=$ low severity, $\mathrm{FM}=$ moderate severity, and $\mathrm{FU}=$ unburned forest), and lettering represents the American Ornithological Union (AOU) alpha codes for bird species. Species with lower values for PC1 had a greater amount of variability explained by CWD cover, and species farther left on the plot were associated with sites with greater CWD

burned areas (Smucker et al., 2005, Kotliar et al., 2007). We similarly found that these species were concentrated within high severity burned areas, though they were also both observed in unburned sites.

We observed that multiple different habitat structures (snag density, tree density, mean snag $\mathrm{DBH}$, and variance in $\mathrm{DBH}$ ) varied among burn severity classes $27 \mathrm{y}$ after fire. Tree and snag density were both significantly higher in unburned sites compared to all other burn categories. Mean snag DBH and variance in DBH both significantly differed by burn severity class. Many studies have similarly found larger diameter snags to be present in burned areas and most likely to contain excavated cavities (Chambers and Mast, 2005). Snag density, mean snag $\mathrm{DBH}$, and variance in $\mathrm{DBH}$ are believed to be associated with increased nesting and foraging potential (Saab and Dudley, 1998; Chambers and Mast, 2005). The northern flicker and the red-headed woodpecker, both predominantly found in burned forests, could 
benefit from large snags (high $\mathrm{DBH}$ ), because they provide increased nesting and foraging opportunities. Similarly, other woodpecker species, like the black-backed woodpecker (Picoides arcticus), have been shown to select for severely burned forests due to increased beetle foraging opportunity (Murphy and Lehnhausen, 1998; Hutto, 2008). Certain beetle species (e.g., Dendrocotonus and Ips), are known to colonize fire-damaged ponderosa pine trees (McHugh et al., 2003) and could be a prime food source for larger woodpecker species. Wildfire is essential for the emergence of many species of insects (Wikars, 2001; Malison and Baxter, 2010) and the emergence of seeds in coniferous trees (Zwolak et al., 2010). Therefore, wildfires provide an abundance of foraging potential for insectivorous and granivorous birds. The mosaic of different burn severities creates unique foraging and nesting opportunities for different cavity dwellers. Black-backed woodpeckers have been described to have a foraging area of 2.6-16.3 ha (Dudley et al., 2012) and other woodpecker species have been described foraging further than 9.3 ha from cavity roosting sites during the nonbreeding season to expand their home ranges (Lohr et al. 2002). Therefore, woodpeckers likely travel across multiple different burn severities that provide different foraging and nesting opportunities. Many primary excavators are considered keystone species, because they create important habitat for many different secondary cavity-using species (Bonar, 2000; Martin et al., 2004). Woodpecker species richness has also been shown to positively correlate with the biodiversity of other forest bird species (Mikusinski et al., 2001). Therefore, in order to provide habitat for a diverse suite of cavity-nesting birds, it is important to understand how habitat characteristics and burn severity impact primary excavators.

The limitation of common bird survey techniques should be considered when interpreting our results. The point-count method used in this study is the most effective at surveying noisy, active, or brightly colored birds (e.g., woodpeckers, bluebirds, wren, chickadee). Although the point-count method is one of the most common survey techniques for bird population estimates, this method has limited abilities to detect birds that are inconspicuous, have intermittent or subtle vocalizations, or have large home ranges (Thompson, 2002; Amundson et al., 2014; Kissling and Garton, 2006). Therefore, low detection rates of American kestrel $(n=2)$, pygmy nuthatch $(n=1)$, and red-breasted nuthatch $(n=1)$ could be the result of survey method, rather than a low abundance within survey sites. More extensive sampling as well as the use of additional survey methods could provide greater insight into the response of these species to the legacy effects of mixedseverity fire.

Like in western ponderosa pine forests, the legacies of mixed-severity wildfires in eastern ponderosa pine forest provide heterogeneous habitat for cavity-nesting birds, driving variations in cavity-nesting bird community assemblages according to level of burn severity (e.g., Smucker et al., 2005; Kotliar et al., 2007; Hutto and Patterson, 2016). However, we note regional differences between our study site and case studies conducted in western ponderosa pine forests researched elsewhere. Our findings highlight the importance of understanding mixed-severity wildfire in eastern ponderosa pine forests. Suppression of fire and frequent use of low severity fire prescriptions since the 20th century has caused landscapes to homogenize, reducing diversity (Perry et al., 2011). Our results suggest these practices can decrease habitat for cavity-nesting species that rely on mixed-severity burns. Although historical wildfire patterns suggest that eastern ponderosa pine forests were largely exposed to low severity fire regimes (Eidenshink et al., 2007), we found that mixed-severity wildfire plays an important role in shaping species distributions and habitat in current eastern ponderosa pine forests. Mixed-severity fire regimes could be essential to the persistence of 
cavity-nesting birds given their potential to create heterogeneous habitat and increase niche space in eastern ponderosa pine forests.

Acknowledgments.-The USDA NIFA McIntire Stennis project (1008861), the Department of Defense Strategic Environmental Research Development Program (W912HQ-15-C-0018), and the University of Nebraska-Lincoln's Department of Agronomy \& Horticulture provided support for this work. The Nebraska Cooperative Fish and Wildlife Research Unit is jointly supported by Hatch Act funds through a cooperative agreement between the U.S. Geological Survey, the Nebraska Game and Parks Commission, the University of Nebraska Agricultural Research Division, Lincoln, Nebraska, the United States Fish and Wildlife Service and the Wildlife Management Institute. We extend special thanks to the Nebraska Game and Parks Commission, especially to Mike Morava at Fort Robinson State Park and Greg Schenbeck at Peterson Wildlife Management Area, for allowing us to conduct this research on their lands. Any use of trade, firm or product names is for descriptive purposes only and does not imply endorsement by the U.S. Government.

\section{Literature Cited}

Amundson, C.L., J.A. Royle, and C.M. Handel. 2014. A hierarchical model combining distance sampling and time removal to estimate detection probability during avian point counts. The Auk., 131(4):476-494.

Arno, S.F., D.J. Parsons, and R.E. Keane. 2000. Mixed-severity fire regimes in the northern rocky mountains: consequences of fire exclusion and options for the future. USDA Forest Service Proceedings RMRS, 15(5):225-232.

BonaR, R.L. 2000. Availability of pileatedBona woodpecker cavities and use by other species. J. Wildl. Manage., 64(1):52-59.

Bregman, T.P., A.C. Lees, N. Seddon, H.E.A. Macgregor, B. Darski, A. Aleixo, M.B. Bonsall, and J.A. ToBias. 2015. Species interactions regulate the collapse of biodiversity and ecosystem function in tropical forest fragments. Ecology, 96(10):2692-704.

Brown, P.M. And C.H. Sieg. 1999. Historical variability in fire at the ponderosa pine - northern Great Plains prairie ecotone, southeastern Black Hills, South Dakota. Ėcoscience, 6(4):539-547.

Chambers, C.L. 2002. Forest management and the dead wood resource in ponderosa pine forests: effects on small mammals. USDA Forest Service, Gen. Tech. Rep. PSW-GTR-181.

AND J.N. MAST. 2005. Ponderosa pine snag dynamics and cavity excavation following wildfire in northern Arizona. Forest. Ecol. Manag., 216(1-3):227-240.

Dillon, G.K., Z.A. Holden, P. Morgan, M.A. Crimmins, E.K. Heyerdahl, and C.H. Luce. 2011. Both topography and climate affected forest and woodland burn severity in two regions of the western US, 1984 to 2006. Ecosphere, 2(12):130. doi: 10.1890/ES11-00271.1.

Donovan, V.M., C.L. WonkKa, and D. Twidwell. 2017. Surging wildfire activity in a grassland biome. Geophys. Res. Lett., 22:5986-5993. doi:10.1002/2017GL072901.

Dudley, J.G., V.A. SaAB, And J.P. Hollenbeck. 2012. Foraging-habitat selection of black-backed woodpeckers in forest burns of Southwestern Idaho. Condor, 114(2):348-357.

Eidenshink, J., B. Schwind, K. Brewer, Z.L. Zhu, B. Quayle, and S. Howard. 2007. A project for monitoring trends in burn severity. Fire Ecology Special Issue, 3(1):3-21.

Elliott, L.H., and D.H. Johnson. 2017. Local-scale habitat associations of grassland birds in Southwestern Minnesota. Am. Midl. Nat., 178(2):165-188.

Fontaine, J.B., AND P.L. KenNedy. 2012. Meta-analysis of avian and small mammal response to fire severity and fire surrogate treatments in U.S. fire-prone forests. Ecol. Appl., https://doi.org/10.1890/ 12-0009.1.

FrANCE, R.L. 1997. The importance of beaver lodges in structuring littoral communities in boreal headwater lakes. Can. J. Zool., 75:1009-1013.

GaNEY, J.L. 1999. Snag density and composition of snap populations on two national forests in northern Arizona. Forest. Ecol. Manag., 119:169-178. 
AND S.C. VoJTA. 2004. Characteristics of snags containing excavated cavities in northern Arizona mixed-conifer and ponderosa pine forests. Forest. Ecol. Manag., 199:323-332.

Google Inc. 2009. Google Earth (Version 5.1.3533.1731) [Software]. Available from http:// google-earth.software.informer.com/5.0/.

Griffiths, R.P., Madritch, M.D., and Swanson, A.K. 2009. The effects of topography on forest soil characteristics in the Oregon Cascade Mountains (USA): Implications for the effects of climate change on soil properties. Forest. Ecol. Manag., (257):1-7.

Grundel, R. and N.B. Pavlovic. 2007. Response of bird species densities to habitat structure and fire history along a Midwestern open-fire gradient. Condor, 109:734-749.

Grsel, L.W. 1961. An ecological study of tree cavities and ground burrows in forest stands. J. Wildl. Manag., 25(1):12-20.

Latif, Q.S., J.S. Sanderlin, V.A. SaAb, W.M. Block, and J.G. Dudley. 2016. Avian relationships with wildfire at two dry forest locations with different historical fire regimes. Ecosphere, 7(5):e01346. 10.1002/ ecs2.1346.

Laughlin, D.C. and Abella, S.R. 2007. Abiotic and biotic factors explain independent gradients of plant community composition in ponderosa pine forests. Ecol. Modell., (205): 231-240.

Legendre, P. and E.D. Gallagher. 2001. Ecologically meaningful transformations for ordination of species data, Oecol., 129(2):271-280, doi:10.1007/s004420100716.

Liebezeit, J.R. AND T.L. George. 2002. Nest predators, nest-site selection, and nesting success of the dusky flycatcher in a managed ponderosa pine forest. Condor, 104(3):507-517.

Hothorn, T., B. Frank, and P. Westfall. 2008. Simultaneous inference in general parametric models. Biom. J., 50(3):346-363.

Hutto, R.L. 1995. Composition of bird communities following stand-replacement fires in northern Rocky Mountains (U.S.A.) conifer forests. Conserv. Biol., 9(5):1041-1058.

2008. The ecological importance of severe wildfires: some like it hot. Ecol. Appl., 18(8):18271834.

AND S.M. GaLLo. 2006. The effects of postfire salvage logging on cavity-nesting birds. Condor, 108(4):817-831.

R.E. Keane, R.L. Sherriff, C.T. Rota, L.A. Eby, and V.A. SaAb. 2016. Toward a more ecologically informed view of severe forest fires. Ecosphere, 7(2):e01255.10.1002/ecs2.1255.

and D.A. Patterson. 2016. Positive effects of fire on birds may appear only under narrow combinations of fire severity and time-since-fire. Int. J. Wildland. Fire, 25(10):A-L.

JohNSGARD, P.A. 2001. The nature of Nebraska: ecology and biodiversity. University of Nebraska Press. Lincoln and London. 28 p.

Johnstone, J.F., C.D. Allen, J.F. Franklin, L.E. Frelich, B.J. Harvery, P.E. Higuera, M.C.Mack, R.K. Meentemeyer, M.R. Metz, G.L.W. Perry, T. Schoennagel, M.G. Turner. 2016. Changing disturbance regimes, ecological memory, and forest resilience. Front. Ecol. Environ., 14(7):369-378.

Kane, V.R., J.A. Lutz, C.A. Cansler, N.A. Povak, D.J. Churchill, D.F. Smith, J.T. Kane, and M.P. North. 2015. Water balance and topography predict fire and forest structure patterns. Forest. Ecol. Manag., 338:1-13.

Kalies, E.L., C.L. Chambers, and W.W. Covington. 2010. Wildlife responses to thinning and burning treatments in southwestern conifer forests: a meta-analysis. Forest. Ecol. Manag., 259:333-342.

Kartesz, J.T. The Biota of North America Program (BONAP). 2015. Taxonomic Data Center. (http:// www.bonap.net/tdc). Chapel Hill, N.C. [maps generated from Kartesz, J.T. 2015. Floristic Synthesis of North America, Version 1.0. BONAP., (in press)].

Kaul, R.B., D.M. Sutherland, and S.B. Rolfsmeier. 2011. The floral of Nebraska second edition. University of Nebraska-Kearney. 50 p.

Kissling, M.L. and E.O. Garton. 2006. Estimating detection probability and density from point-count surveys: a combination of distance and double-observer sampling. The Auk., 123(3):735-752.

Kotliar, N.B., S.J. Hejil, R.L. Hutto, V.A. SaAb, C.P. Melcher, and M.E. Mcfadzen. 2002. Effects of fire and post-fire salvage logging on avian communities in conifer-dominated forests of the western United States. Studies in Avian Biology., (25):49-64. 
P.L. Kennedy, and K. Ferree. 2007. Avifaunal responses to fire in southwestern montane forests along a burn severity gradient. Ecol. Appl., 17(2):491-507.

Kroll, A.J., Y. Ren, J.E. Jones, J. Ciovanini, R.W. Perry, R.E. Thill, D. White, and T.B. Wigley. 2014. Avian community composition associated with interactions between local and landscape habitat attributes. Forest. Ecol. Manag., 326:46-57.

Lehmkuhl, J.F., R.L. Everett, R. Schelhas, P. Ohlson, D. Keenum, H. Riesterer, and D. Spurbeck. 2003. Cavities in snags along a wildfire chronosequence in eastern Washington. J. Wild. Manag., 67(1):219-228.

Lesak, A.A., V.C. Radeloff, T.J. Hawbaker, A.M. Pidgeon, T. Gobakken, and K. Contrucci. 2011. Modeling forest songbird species richness using LiDAR-derived measures of forest structure. Remote. Sens. Environ., 115:2823-2835.

Lohr, S.M., S.A. Gauthreaux, and J.C. Kilgo. 2002. Importance of coarse woody debris to avian communities in loblolly pine forests. Conserv. Biol., 16(3):767-777.

Malamud, B.D., J.D.A. Millington, G.L.W. Perry, and D.L. Turcotte. 2005. Characterizing wildfire regimes in the United States. PNAS., 102(13):4694-4699.

Malison, R.L. and C.V. Baxter. 2010. Effects of wildfire of varying severity on benthic stream insect assemblages and emergence. J. North. Am. Benthol. Soc., 29(4):1324-1338.

Martin, K., K.E.H. Aitken, And K.L. Wiebe. 2004. Nest sites and nest webs for cavity-nesting communities in interior British Columbia, Canada: nest characteristics and niche partitioning. Condor, 106:519.

McHugh, C.W., E.K Thomas, and J.L. Wilson. 2003. Bark beetle attacks on ponderosa pine following fire in northern Arizona. Environ. Entomol., 32(3):510-522.

McPherson, G.R. 1997. Ecology and management of North American savannas. University of Arizona Press. Tucson, Arizona. 119 p.

Mills, T.R., M.A. Rumble, and L.D. Flake. 2000. Habitat of birds in ponderosa pine and aspen/birch forest in the black hills, South Dakota. AFO., 71(2):187-384.

Mikusinski, G., M. Gromadzki, and P. Chylarecki. 2001. Woodpeckers as indicators of forest bird diversity. Conserv. Biol., 15(1):208-217.

MTbS Project (USDA Forest Service/U.S. Geological Survey). 2016. MTBS Data Access: National Geospatial Data.

Murphy, E.C. And W.A. Lehnhausen. 1998. Density and foraging ecology of woodpeckers following a stand-replacement fire. J. Wildl. Manag., 62(4):1359-1372.

Nally, R.M., A. Parkinson, G. Horrocks, L. Conole, and C. Tzaros. 2000. Relationships between terrestrial vertebrate diversity, abundance and availability of coarse woody debris on southeastern Australian floodplains. Biol. Cons., 99(2):191-205.

Nixon, E.S. 1967. A vegetational study of the pine ridge of northwestern Nebraska. Southwest. Nat., 12(2):134-145.

Odion, D.C., C.T. Hanson, A. Aresnault, W.L. Baker, D.A. DessaSala, R.L. Hutto, W. Klenner, M.A. Moritz, R.L. Sherriff, T.T. Velben, And M.A. Williams. 2014. Examining historical and current mixed-severity fire regimes in ponderosa pine and mixed-conifer forests of western North America. PloS ONE., 9(2):e87852. doi:10.1371/journal.pone.0087852.

Oksanen, J. 2012. Constrained Ordination: Tutorial with R and vegan. http://cc.oulu.fi/ jarioksa/ opetus/metodi/sessio2.pdf.

, F.G. Blanchert, M. Friendly, K. Roeland, P. Legendre, D. McGlinn, P.R. Minchin, R.B. O’Hara, G.L. Simpson, And P. Solymos. 2016. Vegan: Community Ecology Package. R package version 2.41. https://CRAN.R-project.org/package=vegan.

Perry, D.A., P.F. Hessburg, C.N. Skinner, T.A. Spies, S.L. Stephens, A.H. Taylor, J.F. Franklin, B. Mccomb, And G. Riegel. 2011. The ecology of mixed severity fire regimes in Washington, Oregon, and Northern California. Forest. Ecol. Manag., 262:703-717.

Petersen, K.L. and A.S Westmark. 2013. Bird use of wetlands in a midwestern metropolitan area in relation to adjacent land cover. Am. Midl. Nat., 169(1):221-228.

Petit, D. R., L. J. Petit, V. A. SAab, and T. E. Martin. 1995. Fixed-radius point counts in forests: factors influencing effectiveness and efficiency. USDA Forest Service Gen. Tech. Rep. PSW-GTR-149 
Raventon, E. 1994. Island in the plains: a black hills natural history. Johnson Books, Boulder, Colorado. $104 \mathrm{p}$.

S AAB, V.A. AND H.D.W. Powell. 2005. Fire and avian ecology in North America: process influencing pattern. $S A B .$, 30:1-13.

AND J.G. DudLey. 1998. Responses of cavity-nesting birds to stand-replacement fire and salvage logging in ponderosa pine/Douglas-fir forests of southwestern Idaho. Res. Pap. RMRS-RP-11. Ogden, UT: U.S. Department of Agriculture, Forest Service, Rocky Mountain Research Station. 17.

H.D.W. Powell, N.B. Kotliar, and K.R. Newlon. 2005. Variation in fire regimes of the Rocky Mountains: implications for avian communities and fire management. SAB., 30:76-96.

Schieck, J. And S.J. Song. 2006. Changes in bird communities throughout succession following fire and harvest in boreal forests of western North America: literature review and meta-analyses. Can. J. For. Res., 36(5):1299-1318.

Schmidt, J.A., B.E. Washburn, T.L. Devault, T.W. Seamans, and P.M. Schmidt. 2013. Do native warmseason grasslands near airports increase bird strike hazards?. Am. Midl. Nat., 170(1):144-157.

Sherriff, R.L., R.V. Platt, T.T. Veblen, T.L. Schoennagel, and M.H. Gartner. 2014. Historical, observed, and modeled wildfire severity in montane forests of the Colorado front range. PloS ONE., 9(9):e106971. Doi:10.1371/journal.pone.0106971.

Sliwinski, M., L. Powell, N. Koper, M. Giovanni, and W. Schacht. 2015. Research design considerations to ensure detection of all species in an avian community. Methods. Ecol. Evol., 7:456-462.

Smucker, K.M., R.L. Hutto, And B.M. Steele. 2005. Changes in bird abundance after wildfire: importance of fire severity and time since fire. Ecol. Appl., 15(5):1535-1549.

Stephens, S.L., J.J. Moghaddas, C. Edminster, C.E. Fiedler, S. Haase, M. Harrington, J.E. Keeley, E.E. Knapp, J.D. McIver, K. Metlen, C.N. Skinner, and A. Youngblood. 2009. Fire treatment effects on vegetation structure, fuels, and potential fire severity in western U.S. forests. Ecol. Appl., 19(2):205-320.

ToLstead, W.L. 1947. Woodlands in northwestern Nebraska. Ecology 28(2):180-188.

Thompson, W.L. 2002. Towards reliable bird surveys: accounting for individuals present but not detected. The Auk., 119(1):18-25.

VERNER, J. 1988. Optimizing the duration of point counts for monitoring trends in bird populations. U.S. Dept. Agric., For. Serv., Res. Note PSW-395.

Weller, T.J. ANd C.J. Zabel. 2001. Characteristics of fringed myotis day roosts in northern California. J. Wildl. Manag., 65(3):489-497.

WienK, C.L., C.H. Sieg, AND G.R. McPherson. 2004. Evaluating the role of cutting treatments, fire and soil seed banks in an experimental framework in ponderosa pine forests of the Black Hills, South Dakota. Forest. Ecol. Manag., 192(2-3):375-393.

WIKARS, L.O. 2001. The wood-decaying fungus Daldinia loculata (Xylariaceae) as an indicator of firedependent insects. Ecol. Bull., 49:263-268.

Zwolak, R., D.E, Pearson, Y.K. Ortega, and E.E. Crone. 2010. Fire and mice: seed predation moderates fire's influence on conifer recruitment. Ecol., 91(4):1124-1131. 